\title{
ALGUNOS CASOS DE TOPONIMIA MARIANA EN EXTREMADURA*
}

\author{
SOME CASES OF MARIAN TOPONYMY IN EXTREMADURA
}

MANUEL MAÑAS NÚÑEZ

Universidad de Extremadura

Recibido: 20/01/2020 Aceptado: 22/04/2020

\section{RESUMEN}

En el presente artículo vamos a examinar una treintena de apelativos raros, extraños o curiosos que otras tantas Vírgenes extremeñas tomaron del nombre del lugar de su aparición, nombres toponímicos todos, muy antiguos, cuyo significado sólo puede comprenderse si los examinamos desde una perspectiva etimológica.

Palabras clave: Lingüística. Toponimia. Extremadura. Nombres de Vírgenes.

\section{ABSTRACT}

This paper analyzes a series of rare, strange or curious names that Virgins of Extremadura adopted from the name of the place of their appearance, toponymic names all,

\footnotetext{
* Este trabajo se inscribe en la línea del Proyecto de Investigación FFI2017-82101-P, dirigido por el
} Dr. D. Luis Merino Jerez y subvencionado por el Ministerio de Economía, Industria y Competitividad. 
very old, whose meaning can only be understood if we examine them from an etymological perspective.

Keywords: Linguistics. Toponymy. Extremadura. Names of Virgins.

\section{INTRODUCCIÓN}

Las advocaciones marianas cobran especial pujanza con la Reconquista, cuyo comienzo en Extremadura podemos fecharlo en 1142, cuando Alfonso VIII logra tomar Coria, la primera plaza extremeña reconquistada. Con la progresiva recuperación del territorio invadido por los musulmanes, van construyéndose los primeros edificios religiosos cristianos, ubicados muchas veces sobre solares donde los árabes, reutilizando en ocasiones edificaciones romanas o visigóticas, habían levantado sus mezquitas. Estamos en plena Edad Media, dominada por doquier por la leyenda y la simbología; en una época de sólido fervor cristiano en mutua interacción con la cultura popular; en un momento histórico de continuas y aceradas guerras de cristianos contra musulmanes o de enfrentamientos civiles entre los propios cristianos; pero, sobre todo, en un periodo histórico caracterizado por la fe y la espiritualidad, materializada en numerosas fiestas religiosas que, mediatizadas por el folclore, acaban adquiriendo, sin perder su sentido religioso, una extensión popular que se ve plasmada en las romerías, donde el pueblo deja ver su devoción a los santos y, especialmente, a la Virgen.

La imagen de la Virgen, rodeada de un hálito de fe, leyenda y milagrería, fue desde bien temprano objeto de culto, pues se veía a la Virgen María como la protectora de pueblos o ciudades contra todo tipo de males. Por ello, los habitantes de las poblaciones, y también los nobles y reyes, se encomendaban a ella, solicitándole milagros, tanto para vencer a los sarracenos y a cualquier enemigo de la fe cristiana como para combatir pestes, enfermedades, hambrunas, sequías o cualquier tipo de calamidades que azotaran a las personas que habitaban los pueblos y ciudades. Hubo además una rica literatura hagiográfica que elogiaba las cualidades y méritos marianos, tales como los Libri miraculorum de Gregorio de Tours, las obras de San Ildefonso de Toledo, Las cantigas de Santa María de Alfonso X, los Milagros de Nuestra Señora de Berceo, el Liber Mariae de Juan Gil de Zamora o los Sermones de Bernardo de Claraval (Mariana 2013, 332-333). 
En este ambiente medieval, legendario y simbólico de exaltación mariana, más tarde favorecido y apoyado en el Concilio de Trento, es en el que se produce la mayoría de las apariciones marianas, que suelen tener un esquema fijo y tipificado. En efecto, en muchos casos la imagen de la Virgen aparece después de haber estado oculta o escondida largos siglos ante la invasión musulmana; la imagen, además, provenía a veces de Tierra Santa; la efigie mariana suele aparecerse o ser encontrada por una persona humilde, de baja condición social e intelectual, que a menudo es un pastor; la Virgen expresa su deseo de permanecer en el lugar donde se aparece, porque es el sitio que ella ha elegido para que le sea erigido un templo o ermita; es también frecuente que, si los aldeanos intentan levantar el santuario en otro lugar que no sea el escogido por la Virgen, ella intervenga para hacerles ver que su voluntad no debe ser transgredida (Ramos 2018, 41-42). De este modo, surgen desde época medieval numerosos oratorios, capillas, santuarios y templos en los que se venerará a la Virgen María, en medio de leyendas que poco importaba que fueran inverosímiles, pues lo que se pretendía desde la fe era que el culto de la imagen de María llegase al fondo del corazón humano.

En la mayoría de los casos, estas imágenes, que ocupan las nuevas iglesias y ermitas que se erigen tras la reconquista y siglos posteriores, se convierten en patronas de las localidades donde se aparecieron o fueron localizadas. Y, como todas son Vírgenes María, hay que ponerles un nombre específico que las diferencie de las demás imágenes del resto de poblaciones. El procedimiento más socorrido es el de poner a la Virgen el nombre del lugar donde se manifiesta, ya sea el nombre de un paraje, un arroyo o regato, un monte, un valle o una dehesa que estén de alguna manera relacionados con el sitio en que tuvo lugar la epifanía de la Virgen o el hallazgo de su imagen. Y es aquí precisamente donde entra en juego la toponimia, pues la Virgen recibe como apelativo un topónimo, un hidrónimo, un orónimo o incluso un fitónimo. Y, aunque la mayoría de estas advocaciones marianas pueda ser relativamente reciente, normalmente de época medieval, sin embargo a las imágenes se les ponen nombres propios de lugar que pueden ser muy antiguos, porque los topónimos, y especialmente los hidrónimos, son siempre anteriores a la veneración mariana y muchas veces existen desde épocas casi prehistóricas. Por ello, para estudiar los distintos apelativos que lleva la Virgen, según el lugar donde se reveló, hay que acudir a la lingüística y, concretamente, a la rama de la misma que estudia el origen de los nombres propios de lugar y el significado de sus étimos, esto es, a la parte de la ciencia lingüística que se ocupa de la toponimia.

Actualmente, gracias al trabajo de Teodoro Fernández (1994), tenemos un censo exacto, conteniendo algunas exhaustivas descripciones, de las más de 450 
advocaciones marianas que hay en Extremadura, repartidas por toda la geografía regional en santuarios, ermitas y parroquias pertenecientes a las diócesis de Coria-Cáceres, Mérida-Badajoz y Plasencia, incluidas también las dependientes de la archidiócesis de Toledo. En muchas ocasiones, esta toponimia mariana es diáfana y no precisa de mayor estudio. Por ejemplo, Nuestra Señora de la Montaña (Cáceres), Nuestra Señora del Puerto (Plasencia), Nuestra Señora de la Cueva (Esparragosa de Lares, Puebla de Alcocer) o Nuestra Señora de la Encina (Burguillos del Cerro), son topónimos claros que simplemente indican si la Virgen se halló en un monte, en un puerto, en una cueva o en un árbol. Estos étimos, de significado tan evidente, los pasamos por alto.

También omitimos el estudio de topónimos marianos ya desentrañados por los etimologistas, como es el caso de Santa María de Guadalupe, patrona de Extremadura, un nombre toponímico (Fernández 1994: 61) tomado del río o arroyo homónimo que pasa por la Puebla, el Guadalupe o Guadalupejo, donde hallamos dos raíces hidronímicas, una árabe (wada> guada) y otra preindoeuropea *lup-/*lub- de origen mediterráneo, que a menudo se ha confundido con la raíz latina del sustantivo lupus, "lobo", asociándose así por homofonía los topónimos que significaban "fuente, agua" con el conocido animal "lobo" $(<l u-$ pum). En Guadalupe tenemos, pues, una tautología, con dos raíces que significan lo mismo: "corriente de agua, río" (Sánchez Salor 1999: 119; Mañas 2019, 41-42).

En el presente artículo vamos a examinar una treintena de apelativos raros, extraños o curiosos que otras tantas Vírgenes extremeñas tomaron del nombre del lugar de su aparición, nombres toponímicos todos, muy antiguos, cuyo significado sólo puede comprenderse si los examinamos desde una perspectiva etimológica. Y, gracias a este análisis lingüístico y toponímico de los nombres de lugar adoptados por muchas Vírgenes extremeñas, vamos a comprobar que en la toponimia de nuestra región quedan restos lingüísticos palpables de las lenguas habladas por los antiguos pobladores que habitaron Extremadura, iberos, indoeuropeos, especialmente celtas, romanos o árabes.

Ofrecemos los nombres de las Vírgenes ordenados alfabéticamente según su apelativo toponímico.

Almocóvar (Alcántara): Tomada Alcántara (Cáceres) por Alfonso IX en 1213, la mezquita musulmana se consagró como iglesia cristiana con la advocación de Santa María de Almocóbar, esto es, "Santa María del cementerio". En 1238 es citada en la confirmación de las pertenencias de la milicia de Alcántara realizada por el papa Gregorio IX como ecclesiam Sancta Mariae de Almocobaria cum hospitale et pertinentiis suis. Ya a finales del siglo XIII, durante el 
maestrazgo de don Garci Fernández Barrantes, se concluye la construcción del templo cristiano (Martín 2009: 644). El apelativo es un arabismo que puede aparecer con distintas variantes: Almocávar, almocave, almocóvar, almacave, almocábar, etc. Significa "cementerio de moros" o "cementerio de judíos". Proviene del árabe clásico almaqabir: "cementerio", pues qabara significa "enterrar, inhumar, sepultar" y qabr, "túmulo". Tenemos la Puerta de Almocábar en Ronda (Málaga), por hallarse junto al antiguo cementerio musulmán. También encontramos un almocovar como "antiguo cementerio de moros" en Lisboa, en el barrio de la Mouraria.

Antolines (Guijo de Galisteo): La imagen de la Virgen de los Antolines (Guijo de Galisteo, Cáceres), según la tradición, fue encontrada dentro del tronco de una encina que había quedado quebrada por un vendaval. Un pastor, entonces, la encuentra y, pensando que era una muñeca, se la llevó al chozo como regalo para su esposa. Como sucede en otras apariciones marianas, la Virgen retorna repetidas veces al mismo sitio de su aparición, en la finca de Los Antolines, por lo que las autoridades eclesiásticas acuerdan edificar una ermita en un altozano de esa finca y depositar allí la imagen de la Virgen, de factura románica.

La Virgen, como vemos, toma nombre de la finca donde se aparece: Los Antolines. Lo habitual es pensar que se trata de un antropónimo y que bajo el nombre de la finca se esconde el nombre de sus dueños, unos supuestos Antolines. Pero nada sabemos de estos dueños así llamados o apellidados. Lo que sí sabemos es hay otros parajes denominados Antolín en Villanueva de la Fuente (Ciudad Real), en Peñarroya-Pueblonuevo (Córdoba), Antolinas en Villabaruz de Campos (Valladolid), una Casa de Antolina en Casas de Millán (Cáceres), Casa de los Antolines en Jumilla (Murcia), el paraje El Antolino en Valdevacas de Montejo (Segovia), Cerro Antolino en Villacarrillo (Jaén), Pozo Antolino en Sigüenza (Guadalajara), Valdeantolín en Tabanera la Luenga (Segovia), Valdeantolinos en Torralba (Cuenca), Cotarro Antolino en Hontoria de Cerrato (Palencia), Páramo de la Antolina en Antigüedad (Palencia) y Parantolina en Espinosa de Cerrato (Palencia).

No puede haber tantos Antolín, Antolina y Antolines que sean poseedores de parajes, valles, cerros y pozos. Realmente, bajo buena parte de estos topónimos citados puede encontrarse el término español tollo (en catalán toll, en bretón toull, en irlandés toll), cuyo significado, según recoge el DRAE, es "hoyo" o agujero en la tierra, también terreno húmedo o charco formado por el agua de lluvia, o lodo y fango en León y Salamanca. Todavía un "atolladero" es un lodazal donde se atascan los carruajes, animales o personas. Son voces de origen 
prerromano, seguramente emparentadas con el céltico *tullon, "agujero" y con la raíz céltica *tol-/ *tel-/ *tul-, "agujero, hondonada". Todos estos topónimos citados, en fin, indicarían que el terreno tiene orificios, agujeros u hondonadas $\mathrm{y}$, en muchos de los casos, que con el agua de lluvia se forman charcos y lodazales que harían de atascaderos. Y el lugar donde se ubica la Ermita de Nuestra Señora de los Antolines en Guijo de Galisteo es un paraje 1lano, rodeado de arroyos y ahora canales de riego, pues es terreno de regadío, tierras, por tanto, húmedas y dadas a formar charcos y lodazales.

Argamasa (Riolobos): La ermita de Nuestra Señora de la Argamasa se encuentra en el paraje homónimo: la dehesa de La Argamasa, en la localidad de Riolobos (Cáceres). Parece que antiguamente estaba situada en la ribera del Alagón, donde cuenta la leyenda que se encontró la imagen de la Virgen flotando en las aguas del río. Esta primitiva ermita fue anegada y arruinada por una crecida del río, por lo que se levantó la actual a principios del siglo XX, reconstruida a finales del mismo siglo. Se denominó Virgen de la Argamasa porque la imagen, como decimos, se encontró en la dehesa homónima (Rodríguez 2011, 16).

El topónimo parece transparente y tiene, sin duda, que ver con el mortero hecho de cal, arena y agua que se emplea en las obras de albañilería. De hecho, es un topónimo que se repite en España dando nombre a casas, cortijos, dehesas, prados e incluso arroyos. Hay así parajes Argamasa en Badajoz (Medina de las Torres y Fuente de Cantos) o en Toledo (Camarena y Aldeanueva de San Bartolomé); un accidente geográfico Argamasa en Guadalajara; parajes La Argamasa en las localidades de Mandayona (Guadalajara), Saelices (Cuenca), Sacedón (Guadalajara), Segura de León, Bodonal de la Sierra o Santa Marta (Badajoz); un Arroyo de la Argamasa en Zarza de Granadilla (Cáceres) y en Segura de León (Badajoz), un Regato de la Argamasa en Malpartida de Cáceres y una Vega de la Argamasa en Hornachos (Badajoz). Otros topónimos relacionados con éste y repartidos por la geografía nacional podrían ser Argamasilla, Argamasilla de Alba y de Calatrava, Argamasón, Argamazón, etc.

En general, se puede afirmar que todos estos topónimos que contienen el término Argamasa o alguno de sus derivados aluden a sitios donde se encuentran restos arqueológicos, ruinas de antiguas edificaciones, muchas veces restos de villae romanas, o simplemente edificios en mal estado. Argamasa, entonces, es una denominación castellana para designar parajes con ruinas, semejante a otras como Villar, Mármoles, Piedras, etc. (Gordón 1992, 429, n. 46).

Argeme (Coria): La Virgen de Argeme es una advocación mariana venerada en Coria (Cáceres). Cuenta la tradición que la imagen de Nuestra Señora Santa María fue escondida en el año 714 para evitar el robo y la profanación de los 
invasores musulmanes. Luego, en el año 1124, esta misma efigie fue encontrada en la misma cueva en la que fue ocultada (Fernández 1994, 105). Otras fuentes aseguran que el hallazgo se produjo en el Barranco de Argeme o Arageme, cuando un labrador tocó con la reja de su arado la imagen y entonces oyó la palabra "Arge"; o cuando vio dicho labrador que su vaca no se movía para no pisar la santa efigie, a lo que el agricultor gritó: “¡Ara, Geme!”, pues la vaca se llamaba Geme. En otras versiones la yunta estaba formada por dos vacas: Ara y Geme. Se ha afirmado, en fin, que Arageme es un término árabe y que significa "barrio o calle de la mezquita, aljama o iglesia" y que procede de las voces árabes Hara(t)-al-Gami, también registrado en otros textos como Harat Algeme (Vallvé 1999, 115-116).

Lo cierto es que el santuario dedicado a la Virgen de Argeme se encuentra alejado de Coria, a unos cinco kilómetros de la ciudad, en pleno campo, sobre un montículo a cuyas faldas corre el río Alagón. Así que, prescindiendo de leyendas populares y de la etimología árabe, pues no se entiende que en campo abierto se encuentre ningún barrio ni calle que lleve a la mezquita o iglesia, es una certeza evidente que la ermita se asentó, ya posiblemente desde época visigótica (Simón 2003, 153), en el paraje conocido como Argeme o Alto de Argeme por ser éste el lugar de la aparición mariana. Este mismo topónimo dio también nombre a la Puebla de Argeme, poblado de colonización moderno. Hemos, por tanto, de pensar que Argeme es un término antiguo y anterior a la invasión musulmana e incluso a los asentamientos romanos.

Lo importante en nuestro caso es que el paraje está ubicado en una elevación (Alto de Argeme) y que se encuentra a orillas del río Alagón. Nuestra propuesta etimológica divide el término en dos componentes: $\operatorname{Ar}(a)$-geme. Primeramente, nos encontramos con la antiquísima raíz hidronímica *ar-, "curso de agua", una raíz precéltica, quizás preindoeuropea, muy común en la hidronimia y oronimia de la Europa Central y también del Sur europeo (Aymar, 1995, 7), el mismo radical presente, por ejemplo, en el río Ara, la Rivera del Ara y en el Valle del Ara, precisamente donde se halla la Ermita de Nuestra Señora del Ara en el pueblo pacense de Fuente del Arco. En cuanto al segundo componente, podemos considerar que esté presente el radical ibérico *geme: "fuerza, energía", emparentado quizás con el urálico *keme: "fuerte, duro", empleado en oronimia para indicar terreno fuerte, duro, elevado, alto. Así, tenemos en Huete (Guadalajara) el paraje Altogeme, posible tautología; el paraje La Gemelana en Valmadrid (Zaragoza); la localidad de Gemenuño o Jemenuño (Segovia), con un elemento muño, "otero, colina", también vasco-ibérico, significando una ubicación dura o elevada; o el topónimo Cuesta del Geme (Segovia), "cuesta dura o de mucha pendiente". Parece, entonces, que el topónimo Argeme que dio lugar a la 
Virgen patrona de Coria es muy antiguo, de posible ascendencia vasco-ibérica, y que su significado está presente ya en el topónimo Alto de Argeme aún conservado, es decir, que etimológicamente significaría algo así como "cerro, colina, elevación a las faldas del río".

Ara (Fuente del Arco): La Ermita de la Virgen del Ara se encuentra en Fuente del Arco (Badajoz). Se cree que es muy antigua y se relaciona con un posible asentamiento romano, porque contiene elementos constructivos que quizás sean romanos o visigodos, por lo que pudo ser en origen un templo de culto pagano, luego cristianizado. Respecto a la aparición mariana, cuenta la leyenda que en época musulmana la Virgen se apareció sobre un ara (de ahí supuestamente su nombre) al rey Jayón y a su hija Erminda, los cuales, al verla, se convirtieron al cristianismo. En el siglo XIV aparece citada en el Libro de la Montería (libro III) de Alfonso XI en estos términos:

La Sierra de Hayon es buen monte de Puerco en ivierno, et a vezes ay osso. Et son las vozerías la una desde los Veneros fasta la senda que va de Guadalcanal a las Casas de don Berenguel; et la otra vozería es entre los Guijos, et esta sierra sobrel Molino de Alfonso Pérez; et que estén homes que deseñen encima dela cumbre. Et son las armadas, la una a la Xara de Cordouiella, et la otra a Sancta María de Lara, et la otra deyuso del Molino de Alfon Perez.

Se están mencionando los actuales topónimos Sierra de la Jayona, Guadalcanal (Córdoba), Casas de Reina (= Casas de don Berenguel), Dehesa Cordobilla y la Ermita de la Virgen de Ara.

Nuestra propuesta etimológica se basa en que la Virgen de Ara de la localidad Fuente del Arco toma su nombre del río Ara, con un radical hidronímico muy antiguo y difundido en España y Europa, el mismo que en Argeme. Es decir, tanto en el nombre del río Ara como en el del pueblo, Fuente del Arco, tenemos la misma base. En efecto, para las formas toponímicas $\operatorname{Arco}(s)$ y sus derivados en España, con abundantes paralelos europeos, especialmente franceses, pensamos que proceden de la raíz hidronímica sufijada *ar-k, muy antigua, quizás paleoeuropea, teniendo en ocasiones derivaciones oronímicas. En nuestro caso, al sureste de Extremadura, en las estribaciones de Sierra Morena y lindando con la provincia de Sevilla, se encuentra el pueblo pacense Fuente del Arco. La primera parte del topónimo no ofrece dudas: es un hidrónimo y se alude a un manantial de agua que brota. En cuanto al apelativo "del Arco", hemos de tener en cuenta que en las inmediaciones del actual pueblo hallamos el curso de agua de la Rivera del Ara, esto es, un río Ara, sobre el Valle del Ara, precisamente donde se encuentra la Ermita de Nuestra Señora del Ara, todo ello enclavado en la Sierra de la Jayona, donde hubo explotaciones mineras desde época romana. 
Parece evidente que en la Rivera del Ara y en el Valle del Ara nos encontramos con la antiquísima raíz hidronímica *ar-, "curso de agua". Y que el pueblo en cuestión tomó su nombre del mencionado radical, ya sufijado *Arko $>$ Arco, "del río Ara", a lo que se le acabó uniendo tautológicamente el término moderno de Fuente. Así pues, el hidrotopónimo Fuente del Arco no aludiría a otra cosa sino a una fuente, manantial o curso de agua relacionado con el río llamado Ara, actualmente Rivera del Ara. Siendo todo ello así, nuestra Virgen del Ara no significa sino "la Virgen del río".

Barbaño (Montijo): Ya en el siglo XVII Bernabé Moreno de Vargas, en el capítulo que dedica a las villas de Montijo, Puebla de la Calzada y Lobón (Historia de la ciudad de Mérida, 5.6), nos da información detallada sobre el nombre de Nuestra Señora de Barbaño y sobre la ermita donde se la venera. Nos informa, en efecto, que la virgen toma su nombre de la Dehesa de Barbaño, porque, allí se erigió su ermita. No obstante, la virgen en cuestión se encontró en las ruinas de la Dehesa de Torre del Águila, fue luego llevada a la Iglesia de San Isidoro $\mathrm{y}$, finalmente, decidieron los vecinos de Montijo levantarle un templo, pero no en la Dehesa de Torre del Águila, que no pertenecía a los montijanos, sino en la Dehesa de Barbaño, que sí era comunal. Además, Moreno de Vargas, señala el parecido que tiene la Virgen de Barbaño con la de Guadalupe y, partiendo de un texto de las Vitas Patrum Emeritensium, concluye que la imagen debe ser de época visigótica, así como los edificios en ruinas donde la talla fue hallada, posiblemente, aduce Moreno, una iglesia parroquial de los poblados que allí había y que acabó derruyéndose tras sufrir alguna de las muchas crecidas del Guadiana. Transcribimos el texto, porque no tiene desperdicio:

Tiene esta villa cerca del río Guadiana una Ermita de nuestra Señora, que llaman de Barbaño, por estar fundada en la dehessa que tiene este nombre; cuya imagen es antiquíssima y de mucha devoción. Hallose entre los edificios antiguos que están arruinados allí cerca y llaman los paredones en la dehesa de Torre del Águila; lleváronla a la Iglesia de San Isidoro y se bolvió por dos vezes al sitio adonde fue hallada; por lo qual los del Montijo se determinaron hazerle una Iglesia, ya que no en aquel sitio, por ser la dehessa agena, la edificaron a su linde en la de Barbaño, que es suya, adonde oy está. La imagen es pequeña, algo morena y muy parecida a la de Guadalupe y a otras que ay en España muy antiguas. Tiénese por cierto fue del tiempo de los Godos, porque es dellos la fábrica de los edificios adonde se halló, que fue alguna Iglesia Parroqual de caserías que por allí estaban y se anegó en alguna creciente de Guadiana, y pudo ser en la que se refiere Paulo Diácono que sucedió en aquel tiempo. Sus palabras son éstas: Memorabilis amnis Ana nimirum excrescens ripasque albei sui supergrediens, fluenta liquoris late aspersit et ruinas aedium per villulas 
vicinas litori suo multas fecit; similiter Caulilianensis Monasterii cellas evertit $^{l}$. (Moreno de Vargas, $293 \mathrm{r}-\mathrm{v}$ ).

$\mathrm{Y}$, efectivamente, en los mapas topográficos actuales aún figuran las dos dehesas mencionadas por Moreno, la de Barbaño y la de Torre Águila. En el caso que nos ocupa, Barbaño, hemos de pensar que se trata de un hidrónimo en cuya base se encontraría la base prerromana *barb-, "nacimiento de agua, humedal, terreno pantanoso". Sería la misma raíz que tenemos en Barbón o Valbón, en su versión deformada. Y es que, en efecto, la Dehesa de Barbaño, situada en las vegas del Guadiana, se encuentra en terreno llano, fácilmente inundable y hoy en día en zona de regadío, por lo que es claramente un paraje húmedo y pantanoso.

En cuanto a la otra dehesa, la de Torre Águila, la etimología parece más sencilla y remitiría a alguna supuesta "torre antigua donde habitara o tuviera su nido algún águila". Pero hemos de tener cuidado, porque, como ha señalado Galmés (2000, 40-41), no siempre que aparece el topónimo Águila, Aguilar, etc. estamos ante un zootopónimo, sino más bien ante un orónimo con base $a c u$ - (del latín acutum, aculeum), "agudo, afilado", modificada por etimología popular en aqui-(>agui-). Teniendo en cuenta que en la Dehesa de Torre Águila se encuentra la villa romana de Torreáguila, hemos de considerar que el topónimo es latino y aludiría a alguna torre romana o quizás posterior que, por pequeña que fuera, debía sobresalir entre los terrenos llanos de la zona. El significado, pues, del orónimo es el de "torre puntiaguda, que sobresale" por su altura, el mismo significado que tiene la Torre Aguileja del mismo paraje.

Begoña (Entrerríos): En Entrerríos (Villanueva de la Serena, Badajoz), situado entre el Guadiana y el Zújar, hallamos la advocación mariana de la Virgen de Begoña, originaria de la anteiglesia de Begoña (Bilbao). Se trata de una Virgen venerada en la geografía española, por ejemplo, en Santa Cruz de Tenerife, Gijón, Miraflores de la Sierra (Madrid), Madrid capital, Alquife (Granada), Puerto de Sagunto (Valencia) y hasta en Venezuela. En Bilbao tenemos la entidad menor Begoñaco Ama y el barrio Begoñaco y el paraje Begoñeta en Gipúzcoa.

Parece, en efecto, que el topónimo es de raigambre eusquérica, aunque con base indoeuropea, y que, como estima Mitxelena, Bedoña y Begoña, junto con la antigua Bedunia de los Astures y Bedoya, podrían ser derivaciones del céltico

$1 \quad$ El texto de las Vitas (2.21) dice lo siguiente: "El memorable río Anas, experimentando una gran crecida y sobrepasando las orillas por donde transcurre su cauce, vertió hasta muy lejos el curso de sus aguas y ocasionó muchas ruinas de edificaciones por las fincas próximas a sus márgenes e igualmente inundó las celdas del monasterio de Cauliana". 
bedo- ("zanja, canal, arroyo, curso de agua"), procedente de la raíz indoeuropea *bhedh-, con el sufijo -onia. Las variantes Bedoña / Begoña se justificarían por la equivalencia acústica entre $d / g$ (Moralejo 1977, 81). Si el topónimo Begoña significa eso y es realmente un hidrónimo, no vemos que pueda haber mejor nombre para la Virgen venerada por un pueblo llamado Entrerríos, caracterizado por estar flanqueado por dos importantes corrientes de agua.

Belén (Cabeza del Buey, Cañamero, Puebla de Sancho Pérez, Zafra): En Cabeza del Buey se erige el Santuario de Nuestra Señora de Belén. Cuenta la tradición que unos pastores vieron repetidas veces la imagen de la Virgen reflejada en las aguas de un arroyo cerca del río Almorchón y también sobre las encinas del lugar. Posteriormente se levantó la ermita como centro de peregrinación y devoción a partir del siglo XII. También en Cañamero, camino de Guadalupe y antes de la cuesta de Puerto Llano, se encuentra la Ermita de Belén, en el valle del río Ruecas y al pie de la llamada Sierra de Belén. Asimismo, hallamos sendas Ermitas de Belén en Puebla de Sancho Pérez y Zafra. Y en Trujillo hay un núcleo urbano de Trujillo llamado Belén. Aunque, en la mayoría de los casos citados, estamos ante advocaciones marianas, no creemos que el topónimo en sí se esté refiriendo a la Virgen María de la famosa ciudad palestina de Belén.

En efecto, como han demostrado Carnoy y Galmés $(2000,90)$, en la toponimia peninsular hay nombres que comienzan por $\mathrm{Bel}$ - y que no tienen nada que ver con el latín bellus, "bello, hermoso", sino con la raíz celta *bel-, "brillante, blanco". La conocida divinidad céltica Belenos da cuenta de ello. Pues bien, esta raíz, aplicada a toponimia, suele hacer alusión a terrenos calizos o calcáreos, pero también a montes y sierras de cuarcita e incluso granito, siempre que el color de la piedra sea blanquecino, brillante o claro. Es lo que ocurre con topónimos peninsulares como Belonga (Asturias), Belmonte (Teruel, Asturias, Cuenca), Belver (Huesca), Belvís (Ciudad Real, Cáceres), etc. Parece, entonces, probable que todas estas Vírgenes de Belén y también el núcleo urbano de Trujillo estén en conexión con esta raíz céltica y con las características brillantes, claras y blanquecinas de los terrenos donde se ubican; podrían incluso estar emparentadas con el dios celta Belenos o Belenus, ya latinizado, que evolucionaría en español a Beleno> Belén, y que se hubiera producido un sincretismo entre las religiones céltica, romana y cristiana.

Berrocosa (Jarandilla): La antigua ermita de la Virgen de la Berrocosa se encuentra en el paraje de Jarandilla (Cáceres) conocido como La Berrocosa. Aún se celebra la fiesta de la Virgen de La Berrocosa consistente en una caminata desde el pueblo a dicho paraje. Según recoge Azedo de la Berrueza en su libro Amenidades, florestas y recreos de la Vera Alta y Baja en la Extremadura 
(1667), la ermita cristiana está erigida sobre un antiguo templo romano, probablemente consagrado a Palas o Minerva, y en esta ermita de nuestra Señora de la Berrocosa documenta Azedo haber visto el monumento funerario con retrato de Attia Avita. Esta estela funeraria del siglo II se cristianizó, fue reutilizada como imagen de la Virgen y, tras ser venerada en la ermita original, finalmente se trasladó a la iglesia parroquial de Jarandilla de la Vera, donde recibe culto cristiano (Edmondson 2001, 110). Así cuenta todo ello Azedo de la Berrueza:

"La ermita de Nuestra Señora de la Berrocosa, que está en medio, camino para el Losar, es muy antigua; y según la inmemorable voz, fue templo dedicado a la diosa Palas. Hállanse en su distrito algunos sepulcros de piedra, claro testimonio que, o fueron del tiempo de la gentilidad, u del tiempo de los moros. Fue esta Imagen desaparecida y en su aparición se halló enterrada y su divino rostro boca abajo. Es hermosísima y así se está del mismo modo que la hallaron, sin que ningún pintor la haya retocado" (Azedo 1891, 55-56).

Efectivamente, la ermita tomó su nombre del paraje La Berrocosa. El DRAE aún recoge el término berrocal como "sitio lleno de berruecos o barruecos", esto es, peñascos graníticos. Se trata, posiblemente, de una voz muy antigua, donde subyace la base prerromana *bar- / *ber-, "roca, monte alto", a partir de la raíz * $B$ - $r$ defendida por Dauzat y Rostaing (Sanz 1997, 90); llevaría añadido un sufijo, seguramente ibérico, $-a c c u$, -есcu y - occu. El resultado toponímico es similar a Los Barruecos (Malpartida de Cáceres), indicando tolmos graníticos.

Bótoa (Badajoz): De la aldea o Dehesa de Bótoa, a $17 \mathrm{kms}$. de Badajoz en dirección a Cáceres, recibe su nombre la Virgen de Bótoa. Allí, en una amplia llanura por la que dirigen su curso los ríos Gévora y Zapatón, se erige ya en el siglo XIV la primera ermita por ser el lugar donde se apareció la Virgen. El nombre es antiguo, al menos de época romana, pues en la zona se han encontrado restos romanos que demuestran que estuvo habitada por romanos y musulmanes. Encontramos el topónimo citado como Budua o Burdua en Ptolomeo (Geogr. 2.5.6) y en el Itinerario de Antonino (419.4). Algunos estudiosos, como Mayer, han considerado el término antiguo Burdua de origen ilirio, remontándolo a un radical indogermánico *bheu- y el antiguo irlandés both, "choza, cabaña", esto es, un lugar habitado. Se trataría de un topónimo hispanocelta que se repite en los textos antiguos con el mismo radical (Budua o Burdoga) en la zona del Bajo Guadalquivir. Sánchez Albornoz ubicó certeramente Budua o Burdua en Bótoa (Pérez 2000, 194).

Actualmente, aún conservamos nombres como Valdebótoa o Vegas de Bótoa, lo que nos indica que hemos de estar ante un hidrónimo y que ese Valle del Bótoa o la Ribera del Bótoa deben corresponderse con el río actualmente 
denominado Zapatón. Así lo atestiguaron Madoz y, antes que él, Fray Francisco de Coria en su manuscrita Descripción e historia general de la provincia de Extremadura (1608), donde nos transmite el nombre por el que el río era conocido en los siglos XVI y XVII, Bótova, y nos hace una descripción que coincide con el actual río Zapatón:

Bótova es un rrío pequeño de la Extremadura. Nace y tiene sus fuentes en las sierras dela Liseda y en otras que confinan con ellas. Sale atravesando la gran Dehesa de Çagala, que es de la mesa maestral de la Orden de Alcántara, rregando sus fértiles tierras y saliendo della se entra en tierras de la ciudad de Badajoz y encaminando sus corrientes al occidente pasa junto a Villar del Rrey, y rrecogendo las aguas que nacen en toda aquella comarca, va rregando todas aquellas dehesas y campiñas $\mathrm{y}$, a una legua antes que emparege con la ciudad de Badajoz, tiene una rrazonable puente a donde se junta con el otro rrío llamado Gébora (fol. 37r).

Se trata, sin duda, del actual río Zapatón, antaño llamado Bótova $>$ Bótoa y que ha de coincidir con la ciudad, seguramente una mansio, que los romanos llamaron Budua, entre Aritium y Plagiaria, posiblemente latinizando la antigua denominación celta. La calzada que venía de occidente cruzaba ambos ríos, el Gévora y Zapatón, dirigiéndose a la vega del Guadiana, donde se hallaba la mansio Plagiaria. En la base de nuestro río Bótoa $<$ Budua seguramente se encuentra el radical hidronímico protocéltico *bod-/ *bud-/ *bed-, "charca, zanja", que en latín dio budo, budonis, "cañaveral" y que aún conservamos en los topónimos El Bodón (Salamanca) (Coca 1993, 216) y en los nombres de pueblos extremeños como Bodonal, Bohonal, etc., incluido el del Río Bodión del sur de Badajoz. Semánticamente, se puede orientar el hidrónimo Bótoa como indicador de "charco, pantano", o, según nos indica Fray Francisco de Coria, como un río nutrido por multitud de manantiales que hacen que el terreno por donde transcurre su curso sean lugares cenagosos y pantanosos, esto es, las propias vegas del río que indican los topónimos actuales Valdebótoa y Vegas de Bótoa, muy fértiles precisamente por ser terrenos húmedos y pantanosos. Si estamos en lo cierto, nuestro topónimo mariano Virgen de Bótoa no alude sino a la aparición de la Virgen en las vegas de este río Bótoa y su significado sería algo así como "Virgen de un río encenagado por multitud de manantiales, en un terreno pantanoso". No en vano actualmente son fecundas tierras de regadío.

Botós o Botoz (Puebla del Prior): Al norte de la Puebla del Prior (Badajoz) se encuentra la ermita de Nuestra Señora de Botós del siglo XVI, a orillas del Arroyo Botós o Botoz. Está claro que la Virgen toma nombre del hidrónimo Botoz, donde hallamos el mismo radical hidronímico protocéltico *bod-/ *bud- 
/ *bed- que veíamos en Bótoa. Asimismo en Laín (Pontevedra) hay una parroquia Botos ("terreno encenagado, pantanoso") a orillas del río Asneiro.

Cabezón (Cañaveral): También posee su propia leyenda Nuestra Señora de Cabezón, cuya ermita se encuentra en el paraje que aún hoy se denomina Cabezón, junto a la calzada romana y a la Cañada Real de Merinas, al lado de la Rivera de Cáceres (antiguamente Arroyo de la Rivera de Cabezón) y no muy lejos de Grimaldo y del conocido como Encinar de Cabezón.

Cuenta la tradición que un pastor de Holguera, guiado por una de las vacas que apacentaba, y que no eran suyas, sino de un vecino de Cañaveral, encontró en unos matorrales la imagen de nuestra Señora de Cabezón. Se entabló entonces una disputa entre los vecinos de Holguera y Cañaveral por la propiedad de tal imagen mariana, zanjándose la discusión a favor de los cañaveraliegos, pues la propia Virgen, ante los ruegos y oraciones del pastor, manifestó que quería permanecer en el pueblo que guardara relación con el fruto que ella llevaba en la mano, una lima, un cítrico que se cultivaba habitualmente en Cañaveral y por el que el pueblo en cuestión era conocido como "Cañaveral de las Limas". La Virgen, por tanto, permaneció en Cañaveral y se alzó un santuario en el paraje conocido como Cabezón, donde actualmente se encuentra la ermita. Esta es, a grandes rasgos, la historia legendaria que se esconde tras Nuestra Señora de Cabezón, cuyo culto se remontaría al menos a finales del siglo XIII, época en la que también se conocía ya el paraje con el nombre de Cabezón.

En 1257, según la Crónica de la Orden de Alcántara de Torres y Tapias (1763, 365-366), Cabezón pertenecía entonces a la Orden del Temple, pero en ese mismo año los freyres de la Orden de Alcántara, para hacerse con este lugar estratégico, atacaron y saquearon Cabezón, Cañaveral, Alconétar y Garrovillas. Y se aclara en este pasaje de la Crónica que Cabezón era entonces tanto villa como castillo y que se ubicaba, bien entre Alconétar y Cañaveral, bien junto a Cañaveral camino de Plasencia, no lejos de Grimaldo. En todo caso, se añade que aún en el siglo XVIII quedaban ruinas de esta villa y castillo y una ermita que los lugareños llaman de Nuestra Señora de Cabezón.

En el Catastro de Ensenada (1753) figuran las dehesas de "Cabezón y Monrobel", que actualmente aparece en los mapas como Dehesa de Moncobel.

Por tanto, Nuestra Señora de Cabezón recibe su nombre de la Dehesa de Cabezón donde fue encontrada y en la que, según parece, antiguamente hubo villa y castillo. El étimo Cabezón es un orónimo, está emparentado con el sustantivo latino caput y es muy empleado metafóricamente en toponimia para indicar un "cerro alto". Más concretamente, el término deriva del latín vulgar hispánico capitiu(m), "cabeza", con el sufijo aumentativo -ón, precisamente 
porque dicha Dehesa de Cabezón se encuentra en un monte o cerro de cierta elevación. De hecho, en mapas catastrales el paraje figura como Los cabezones, por la abundancia de "montículos".

Carrión (Alburquerque): En el paraje conocido como Carrión, a la orilla derecha del río Gévora, camino de La Codosera, se encuentra la Ermita de la Virgen de Carrión (Alburquerque). Cuenta la leyenda que en el Cerro de los Castillejos, cercano al santuario de la Virgen de Carrión, tuvo lugar una batalla entre moros y cristianos, comandados éstos por el general Carrión, en referencia a D. Alonso Téllez de Meneses, de la familia poseedora de la Villa de Carrión de los Condes de Palencia. En dicha batalla los musulmanes fueron vencidos por la intervención mariana, por lo que Alburquerque erigió un santuario a la Virgen, le puso del nombre de Virgen de Carrión y le concedió además el título honorífico de Generala, incluidos fajín y vara de mando. La leyenda ha sido ya refutada por diversos investigadores (Rodríguez 2012).

Esta Virgen de Carrión ha dado también lugar a un refrán que remite a la época de la maduración de las frutas: "Por la Virgen de Carrión, deja la sandía y vete al melón", en referencia al día de la natividad de la Virgen (el 8 de septiembre).

Realmente, hemos de olvidarnos de las tradiciones populares y centrarnos en el paraje donde la Virgen se apareció, esto es, en el paraje Carrión. En la base del topónimo se encuentra la raíz prerrománica *karr-, que significa "piedra, roca”, y que ha sido muy productiva en la toponimia española: Carrión (Málaga), Carrión de Medina (Valladolid), Carrió (Asturias y Mallorca), Carroceda (La Coruña), Carracedo (León, Palencia, Lugo), Carral (La Coruña), Carrandi (Asturias), Carranza (León), Monte Carria (Asturias), Alcarria (Guadalajara), Karragutxi, Karranza, Karranzeta o Karriarán (País Vasco) (Galmés 2000, 3233). Nuestra Virgen de Carrión, por tanto, no significa más que la Virgen aparecida en un paraje lleno de piedras y rocas, la "Virgen del pedregal". Y, por cierto, junto a este paraje Carrión se encuentra otro llamado Moral, que nada tiene que ver con la abundancia de moras (ni con mujeres musulmanas ni con el fruto de la morera o del moral), sino con la raíz prerrománica *mor-, "montón de piedras". Los dos topónimos significan lo mismo, en alusión a lo pedregoso del terreno.

Chandavila o Chandávila (La Codosera): En el paraje Chandavila de La Codosera se alza la Ermita de la Virgen de Chandavila, precisamente en donde en 1945 una niña, Marcelina Barroso, acompañada de su prima, vio a las tres de la tarde un bulto grande y oscuro junto a un castaño; más tarde, al regresar por el mismo lugar, percibió de nuevo ese bulto, se acercó y entonces, cuando la 
figura se aclaró y perfiló diáfanamente, se dio cuenta de que era la Virgen, que en días posteriores se le volvió a aparecer. Dos años después se construyó el Santuario mariano.

La Virgen, pues, debe su nombre al paraje Chandavila, un compuesto de chan, versión castellana del gallego y portugués chão (del latín planus), del artículo contracto $d a$ y del sustantivo vila, significando así "llano del pueblo". Hay otro Chandavila en Pontevedra (Bordones) (Barajas 1980, 319).

Cincho (Jarandilla): La ermita y templo de Nuestra Señora del Cincho, según descripción de Azedo (1891, 58-59), está a "dos leguas y media" de Jarandilla de la Vera (Cáceres) y pertenece a su jurisdicción. Se encuentra junto a la Garganta de Cuartos, cerca de donde se une con el río Tiétar. Aún hallamos en el lugar la llamada Vega del Cincho, entidad menor dependiente de Jarandilla y el conocido como Puente del Cincho (Losar de la Vera). Sigue contando Azedo que esta imagen de la Virgen del Cincho la ocultaron los cristianos durante la invasión musulmana y posteriormente apareció, siendo una Virgen que ha obrado muchos milagros y su templo muy visitado por los devotos en romería, especialmente los lisiados, pues es fama que los cura.

El topónimo en cuestión del que toma nombre la Virgen es El Cincho, del latín cingulum, "ceñidor, aro, círculo". Es una forma toponímica ampliamente documentada, por ejemplo, en Sevilla en hidrónimos y orónimos como Arroyo del Cincho o La Cabeza del Cincho; pero también hallamos el Alto del Cincho (Cantabria); Peña Cincho (Burgos); Cerro del Cincho (Utrera, Carmona, Ronda); El Cincho (Burón, Santiago del Tormes, Brañosera, Cazalla de la Sierra, Campo de Yuso, Badajoz, Perales del Puerto, etc.); o las formas Cincha, Cinchadilla, Chincera, Cingla, etc. Según Ruhstaller (1995, 28-29), esta voz cincho no puede justificarse toponímicamente con ninguna de las acepciones que recogen los diccionarios de español. Es indudable, entonces, que hemos de entenderla en un sentido orográfico, quizás con el valor de "cerro", como apuntan Gordón y Ruhstaller (2010, 294), acaso redondeado. No obstante, en el caso de nuestro topónimo verato El Cincho creemos que puede contemplarse otra interpretación, pues, considerando que tal voz procede con toda seguridad del latín cingulum, "cíngulo, cinturón, aro, círculo", hemos que tener en cuenta que el paraje en cuestión se encuentra "rodeado", como en una especie de círculo, por distintas corrientes de aguas, a saber, por la Garganta de Cuartos, por el río Tiétar y por el río Moros. De ahí, que el paraje llegara a denominarse El Cincho.

Coronada (Trujillo, Medina de las Torres, Villafranca de los Barros): La advocación a Nuestra Señora de la Coronada o Virgen de la Coronada es frecuente en Extremadura, hallándola en Trujillo (Cáceres) o en Medina de las 
Torres y Villafranca de los Barros (Badajoz) y, fuera de Extremadura, en Calañas y Cortelazor (Huelva). Como topónimo lo encontramos en nombres de poblaciones como La Coronada en Badajoz; también como designación de parajes, como La Coronada Alta en Fuente Obejuna (Córdoba), o de montañas, como La Coronada en Garbayuela (Badajoz). Hallamos también el paraje Coronado en Álora (Málaga), Almodóvar del Campo (Ciudad Real), Corte de Peleas, Zalamea de la Serena (Badajoz) o en Castril (Granada). Asimismo lo vemos en hidrónimos, tales como Arroyo de las Coronadas (Córdoba), Arroyo de Coronado (Ciudad Real), Arroyo del Coronado (Sevilla), Noria de Coronado (Jaén), Pozo Coronado (Cuenca) y La Encoronada o Punta la Encoronada, en la playa de Luarca (Asturias).

Como observamos, se trata de topónimos, en su mayoría orónimos, y nuestras Vírgenes han tomado su nombre, no por llevar coronadas sus cabezas por coronas o diademas, sino de los lugares o parajes donde se aparecieron o se levantaron sus santuarios. Y es que el sustantivo corona (del latín corona) y sus derivados, como coronado, coronada, coronilla, etc. tienen la acepción oronímica de "la parte más alta o eminente de un terreno o monte" y en el DRAE aún se recoge la acepción de "cima de una colina o de otra altura aislada"; oronímicamente indica también por vía metafórica "cerro que termina en un llano", "meseta" (Selfa 2001, 16).

Así, por poner algún ejemplo, la ermita de Nuestra Señora de la Coronada, en Trujillo, se encuentra en la finca La Coronada, en una suave mesetilla, donde también encontramos el Cerro de la Coronada de $545 \mathrm{~m}$. Asimismo el pueblo de La Coronada se encuentra en lo alto de una suave loma. Y la Ermita de la Coronada en Medina de las Torres se halla en un pequeño alto frente a la ermita del Santísimo Cristo del Humilladero, pasando entre ambas el Arroyo del Valle.

Esparia (Maguilla): En las afueras de Maguilla (Badajoz), precisamente en el paraje denominado Las Esparias, se encuentra una ermita llamada de la Virgen de Esparia, que ya en época de Madoz (1848) estaba en estado ruinoso. El Interrogatorio de la Real Audiencia de Extremadura, partido de Llerena (1791), aclara que es la única ermita extramuros que tiene Maguilla. Y en otro Interrogatorio más antiguo, el de la visita de la Orden de Santiago de 1575, se ofrece la información de que nuestra ermita "está en un cerro como a tres tiros de ballesta". Nos encontramos toponímicamente con el sufijo abundativo latino -aria, unido a la raíz preindoeuropea (Corominas 1972, 94) o ibérica (Rivas 1982, 94) *par-(r)-/ *spar-(r), "extender", que vemos en "esparcir, desparramar, esparrancar, parra, parrulo", etc. El matiz toponímico sería el de "campo raso que se extiende, extensión que abarca una cosa" (Sanz 1997, 73). A pesar de que dicha 
ermita pudiera estar en un cerro, como nos informa el antedicho Interrogatorio, el vocablo Esparia aludiría a los abundantes llanos que desde dicha elevación podrían observarse. Así, el paraje Las Esparias, donde se encontraba la ermita, significaría algo parecido a "los llanos" y la Virgen de la Esparia vendría a ser equivalente a la "Virgen de los llanos". Un significado similar es el del propio nombre Maguilla, en el que creemos ver el término antiguo, seguramente celta, magos: "campo, llano", con el sufijo derivativo ya romano - ela: de un supuesto *Mag-ela se pasaría a *Magila> Maguilla.

Hitos (Alcántara): La ermita de la Virgen de los Hitos de Alcántara, dice el cronista Frey Alonso de Torres y Tapias, tenía ya un notable culto en el siglo XIII y a finales del siglo XIV, según leemos en la Crónica de la Orden de Alcántara, el ermitaño, un fanático, profetizó al maestre Frey Martín Yáñez de la Barbuda que tomaría Granada a los moros, empresa a la que el maestre se lanzó desoyendo todos los consejos sensatos del Rey y muriendo en tan temeraria acción (Fernández 1994, 89).

El término Hito es evolución del latín fictum, "clavado, hincado", participio pasivo secundario, tardo-vulgar, del verbo fingere; y en zonas fuertemente romanizadas alude a los miliarios, las señales más características de las vías romanas, que tradicionalmente se reutilizaron como hitos, mojones, lindes y delimitadores de propiedades rústicas y territorios y que dieron luego paso a topónimos del tipo Val de los Hitos o Cerro de los Hitos (Mérida). Pues bien, el santuario de la Virgen de los Hitos, que se encuentra a cinco kilómetros de Alcántara, bien puede hacer referencia a estos miliarios romanos. Pero también se encuentra la ermita cerca del paraje Carrascal de los Hitos, donde hay restos prerromanos, por lo que estos Hitos pueden referirse a microlitos y macrolitos, a dólmenes, menhires, cazoletas y pedreras de cultos sagrados de los indígenas prerromanos, una especie de santuarios primitivos que, una vez cristianizados, dieron lugar a ermitas cristianas, en este caso a la de la Virgen de los Hitos, quizás relacionada originalmente con la fecundidad o con los sentimientos funerarios de ultratumba (Domínguez 1991).

Jarrera (Mirabel): Nuestra Señora de la Jarrera es la patrona de Mirabel. Además La Jarrera o La Herrera es una dehesa de Mirabel (aunque actualmente pertenece al término municipal de Malpartida de Plasencia), donde se halló un pedestal con inscripción (Madruga 2012). Tenemos allí la Sierra de la Herrera, la Dehesa de la Herrera, el Arroyo de la Herrera, el Alto de la Herrera y, lo que nos interesa, Ermita de la Herrera.

También en este caso la aparición de la Virgen está llena de misterio y leyenda. Unos dicen que la imagen fue desenterrada por un labrador al que se le 
enganchó el arado en una de las asas de una vasija o "jarra" en cuyo interior halló la imagen de la Virgen. Otros dicen que un pastor desplazó una gran roca para coger unas plantas y descubrió entonces la imagen de la Virgen. Se decidió erigir una ermita, no en el lugar del hallazgo, sino cerca del pueblo; pero cada vez que los albañiles empezaban las obras, las herramientas desaparecían y aparecían junto al lugar del hallazgo, de lo que se concluyó que había que levantar la ermita en el lugar donde la Virgen se había aparecido (Rodríguez 2012).

El topónimo La Jarrera es extraño y parece que es el que, por ser derivado de "jarra", influyó en la exégesis popular de esta aparición mariana. Hemos de considerar que este apelativo no deriva de "jarra", sino que se trata de una deformación lingüística, por aspiración de la $h$ - inicial de La Herrera $>L a$ Jerrera $>$ La Jarrera. Está claro que es así. No obstante, lo de la "jarra" podía tener cierta base arqueológica, porque es sabido que en la dehesa La Herrera hay yacimiento romano, villa y necrópolis. Debía ser habitual que los habitantes del lugar encontraran en dicho paraje restos de cerámicas y de ánforas que les pudieran parecer "jarras".

El dilema ahora es dilucidar qué significa el topónimo La Herrera. Lo más evidente, si nos atenemos a la diafanidad del término, es que esté relacionado con el latín ferrum, "hierro", y que aluda a actividades metalúrgicas ("herrero, herrería", etc.). No obstante, dudamos que el topónimo tenga este sentido. Creemos importante la presencia del Arroyo de la Herrera en el paraje que comentamos, tanto que, en nuestra opinión, es el que da nombre a la dehesa, al cortijo, a la sierra, al alto y, en fin, a la ermita, porque, como es sabido, los hidrónimos son los términos que mejor se han conservado a lo largo de los siglos (los cursos de agua han existido siempre). De hecho, en muchas ocasiones, cuando aparece el topónimo Herrera, lo hace en parajes en los que destaca algún curso de agua, a veces un río importante, como, por ejemplo, en la Ermita de Nuestra Señora de Herrera (Zaragoza), junto a la Sierra de Herrera, cerca de la localidad Herrera de los Navarros y, lo más interesante, al lado del Río de Herrera. Lo mismo ocurre en Herrera (Sevilla), cruzado por el Arroyo Pilancón y muy cerca del Río Genil; en Herrera de Duero (Valladolid), junto al Duero; en Herrera de Pisuerga (Palencia), junto al río homónimo y al Río Burejo; en Herrera de Soria, junto a numerosos arroyos y a Fuente Herrera; en Herrera de Valdecañas (Palencia), junto al río Arlanzón; en Herrera de Valdivieso (Burgos), muy cerca del Ebro; en Herrera de Camargo (Cantabria), junto a la Ría del Carmen; o Herrera de Ibio (Cantabria), flanqueado por el Arroyo Ceceja y el importante Río Saja. Y, centrándonos en Extremadura, encontramos Herrera del Duque (Badajoz), cabe al Guadiana; Herrera de Alcántara (Cáceres), junto al Tajo; Herreruela (Cáceres), junto al río Salor o el mismo Puerto de las Herrerías (Cáceres), en 
el paraje Las Herrerías, cruzado por el Arroyo del Aceite y cerca de los ríos Ayuela y Aljucén. En Galicia tenemos la variante Ferreira de Pantón, junto al Río de Ferreira, y en Portugal Ferreira do Zêzere, junto al río homónimo.

Son, en fin, sólo algunos ejemplos, de los muchos que hay, que pueden probar que el topónimo Herrera es realmente un hidrónimo y que se encuentra casi siempre cerca de algún curso de agua importante, siendo además claro que frecuentemente lleva un apelativo tautológico que redunda en su cualidad hidronímica, como en Herrera de Duero, Herrera de Pisuerga, Herrera de Ibio (la raíz *ib-, como en nuestro río Ibor, es hidronímica) etc. Creemos, en realidad, que bajo el vocablo Herrera está la raíz hidronímica indoeuropea *bher, "bullir, hervir, borbotar" (cf. latín ferveo, fervo), referida al agua que bulle, hierve o brota y alusivo a manantiales o cursos de agua abundantes, rápidos, fuertes o espumantes. De ahí, pensamos, proviene la raíz ya castellanizada Her-/ Fer-, que con distintos sufijos (-era, -ería, etc.), daría los topónimos Herrera, Herrerías, Ferreira, etc. que hemos comentado.

Mayorga (San Vicente de Alcántara): En San Vicente de Alcántara (Badajoz) encontramos la Ermita de la Virgen de Mayorga, cuya romería se celebra el primer domingo de mayo. El lugar donde se ubica, y de donde toman nombre la Virgen y la ermita, es la Dehesa de Mayorga, de cuya antigüedad da cuenta el poblado prehistórico del paraje Galana de Mayorga. El topónimo en cuestión da también nombre a la Sierra de Mayorga y al Castillo de Mayorga, asentado en el Alto de Mayorga (449 m.). Se repite el topónimo en la localidad de $\mathrm{Ma}$ yorga (Valladolid) o Maiorga (Portugal); también en los parajes Mayorga de San Martín y Mudrián (Segovia), de Campillos (Málaga) y de Cuacos de Yuste (Cáceres); y en (Las) Mayorgas de Manzanares (Ciudad Real) o de Jerez de los Caballeros (Badajoz). Está estudiado que estos nombres de lugar aluden a elevaciones del terreno y que contienen posiblemente una base oronímica *mai-, "mesa", "tabla", "rellano de altura", de origen prerromano, quizás ibérica, presente en topónimos como Maya, Amaia/ Amaya, Maiorga/ Mayorga, etc. (Díez 1990, 196). El nombre de la Dehesa de Mayorga es muy antiguo, acorde a la antigüedad de los pueblos prehistóricos que habitaron el lugar y dejaron allí sus restos materiales y lingüísticos.

Monfragüe (Torrejón el Rubio): La Ermita de Monfragüe, en Torrejón el Rubio (Cáceres), está situada en el patio de armas del Castillo de Monfragüe y cuenta la tradición que la Virgen fue traída desde Tierra Santa en el siglo XII por los cruzados de la Orden de Monte Gaudio de Jerusalén, orden religiosa de caballería que daría luego lugar a la desaparecida Orden de Monfragüe (Muñoz 1953). 
Toma la Virgen nombre de la Sierra de Monfragüe, un orónimo que ha estudiado Sánchez Salor y que lo que indica es una fractura en el terreno, un mons fractus. Así ocurre con el topónimo Fraga (Huesca) y otros lugares que remontan claramente a fracta, participio del verbo latino frango, "quebrar, romper", aludiendo a un terreno escabroso. Monfragüe remonta, pues, a mons fractus, "monte roto", por las frecuentes y abundantes fracturas del terreno (Sánchez 1999, 127-129).

Navelonga (Cilleros): A unos dos kilómetros de Cilleros (Cáceres), en una amplia meseta de $420 \mathrm{~m}$. de altitud, se yergue la ermita de Nuestra Señora de Navelonga, erigida en el siglo XVI con añadidos posteriores. El nombre de la ermita y Virgen, Navelonga, parece de significado diáfano: "navío largo", con reminiscencias marineras procedentes de la leyenda según la cual unos habitantes de la localidad, emigrantes a las Indias, introdujeron el culto tras verse salvados de un naufragio por intercesión de la Virgen; o bien fue un solo náufrago quien, tras hacer fortuna en América, regresó a Cilleros. No obstante, otra tradición cuenta que la Virgen se apareció a un pastor.

El topónimo, sin embargo, nada tiene que ver con naves ni barcos que volvieron de Indias. Realmente, ha intervenido la toponimia mítica y el hablante ha deformado la palabra que, aun así, la encontramos bien transcrita en los mapas antiguos y modernos. La Virgen debe su nombre al lugar donde se erige la ermita, el paraje Navalonga, repetido, por ejemplo, en Zarza de Granadilla (Cáceres) y en Buitrago de Lozoya (Madrid). Hay además repartidos por la geografía española numerosos topónimos como Navalonga, Navalonguilla o Navalongo que indican tanto accidentes geográficos como cursos de agua. El paraje, pues, donde está la ermita de la Virgen de Navelonga en Cilleros es una nava, esto es, un terreno sin árboles y llano, a veces pantanoso, y situado generalmente entre montañas. El origen del término, aunque obscuro, suele admitirse que es prerromano. Es el mismo componente que tenemos, por ejemplo, en Navalmoral o en Navas del Madroño (Cáceres). Y esta de Cilleros, además, es una "nava alargada" que transcurre a lo largo de la Sierra de Santa Olalla (Rodríguez 2013, 83-84).

Ojaranzo u Hojaranzo (Guijo de Granadilla): En Guijo de Granadilla (Cáceres) se halla la Ermita de Nuestra Señora de Ojaranzo, en ruinas desde la invasión francesa, en un paraje muy denso de arboleda (Fernández 1994, 128). Tenemos también la dehesa Ojaranzo en Casillas de Coria y el paraje y fuente Ojaranzo en Villar del Pedroso (Cáceres). Lo habitual es conectar estos topónimos con el ojaranzo o "almez", considerándolos así fitónimos. No obstante, si tenemos en cuenta que el sufijo -anzo, -anza ( $<$ antia) es abundante en hidrónimos paleoeuropeos (Moralejo 2005), cabría la posibilidad de que estuviéramos 
ante una raíz del antiguo europeo *sar-/*sor-: "fluir, correr, discurrir", la misma que encontramos, por ejemplo, en el río Jarama o en nuestros pueblos Jarandilla o Jaraíz (Cáceres). Por Guijo de Granadilla y Casillas de Coria transcurre el caudaloso río Alagón y en Villar del Pedroso tenemos el hidrónimo Fuente Ojaranzo, con lo que este étimo Ojaranzo sería un hidrónimo que pudiera remontarse a un hipotético *Sar-antio > *Jaranzo, luego deformado por etimología popular en Ojaranzo, quizás por asimilarlo al "ojaranzo" o almez.

Romana (Piedras Albas): En Piedras Albas (Cáceres) se encuentra la Iglesia de Nuestra Señora de la Romana de los siglos XVI-XVII, homónima de la Virgen del despoblado de Brugel (Toledo), del que se cuenta que lo fundaron los romanos y que, como la imagen de la Virgen es o parece antigua, se le dio el nombre de Nuestra Señora de la Romana. Lo mismo podría pensarse del pueblo cacereño. No obstante, resulta posible conectar este topónimo con los muchos lugares gallegos llamados Roma, con el asturiano Romadonga y quizás con el cacereño Romangordo. Está estudiado que es un término céltico y que la voz del irlandés antiguo $r>m$ (ruam), "lugar consagrado, cementerio de santos, cementerio", basada en el nombre de la ciudad italiana de Roma, fue empleada por hablantes célticos cristianizados (Cabeza 2014, 451). No sería descabellado, a falta de mayor información sobre la advocación de la Virgen de la Romana, conectarla con esta voz céltica cristianizada Roma, con el significado de "cementerio", algo así como la "Virgen del cementerio", y relacionarla con el lugar de Piedras Albas llamado Peña Buraca o Canchal de los dos ojos, un santuario rupestre prehistórico cerca del que se hallan tumbas antropomorfas.

Salor (Torrequemada): A tres kilómetros de Torrequemada (Cáceres) se alza la ermita de Nuestra Señora del Salor, fundada por los templarios en el siglo XIII, perteneciendo durante los primeros siglos a la Orden de Santiago, cuya sede estaba en la Iglesia de San Mateo de Cáceres. También esta Virgen del Salor, que fue patrona de Cáceres durante mucho tiempo, está rodeada de leyenda y se cuenta que se apareció a un pastor en el siglo XIII y le anunció que había una imagen suya escondida que, una vez encontrada, fue objeto de culto fervoroso. Al estar ubicada en un pequeño cerro a orillas del río Salor, recibió su nombre de este río.

En cuanto al hidrónimo Salor, está estudiado que procede de una raíz hidronímica *sal- muy antigua, prerromana, que está en la base de hidrónimos como Salmantica (>Salamanca), Sella o Jalón (Sánchez Salor 1977).

Sequeros (Zarza la Mayor): Nuestra Señora de Sequeros (Zarza la Mayor, Cáceres) procede, según parece, del castillo y finca de Benavente desde la Edad Media. Antiguamente, en efecto, el Santuario de Sequeros estaba en la Dehesa 
de Benavente, lejos del municipio, por lo que a principios del siglo XVI se reconstruyó el santuario en un lugar más cercano a la población, precisamente en el paraje denominado Los Sequeros o simplemente Sequero. Se trata de un término que aparece como sustantivo en el Diccionario de la Real Academia Española con los significados de "tierra muy seca, sin riego, o paraje destinado a secar algo". Pero está ampliamente estudiado que en toponimia muchas veces el adjetivo seco o seca o también sus derivados, como el sustantivo sequero, lejos de aludir a la ausencia de agua, lo que indican precisamente es su presencia, esporádica u ocasional, a través de una raíz hidronímica indoeuropea *sek- / *sik-, con el significado de "agua que corre" y aludiendo a los cauces de aguas pluviales, aunque sean estacionales (Cortés 2008, 275). Y en efecto, este paraje Sequero o Los Sequeros de Zarza la Mayor se caracteriza por tener a su alrededor numerosas fuentes como la de la Fontanina, la de la Alberca, la del Puerto o la de las Majadillas, aparte de algunos regatos. Por tanto, el significado del topónimo Los Sequeros no está indicando "tierras secas", sino el paraje abundante en aguas en donde se halla la Ermita de la Virgen de Sequeros.

Es el mismo topónimo que encontramos, por ejemplo, en la localidad de Sequeros, en Salamanca, en plena Sierra de Francia y con una abundancia de aguas contrastada, un pueblo que, casualmente, está también ligado legendariamente a la aparición de la imagen de la Virgen de la Peña de Francia, pues la joven (la profetisa Juana o la Moza Santa) que, según la tradición, vaticinó el descubrimiento de dicha imagen era precisamente del Sequeros salmantino.

Sopetram o Sopetrán (Jarandilla, Almoharín): Nuestra Señora de Sopetrán es la patrona de Jarandilla de la Vera y de Almoharín (Cáceres), en donde asimismo hay un Arroyo de Sopetrán. También encontramos el Monasterio de Sopetrán, en el paraje homónimo de Torre del Burgo (Hita, Guadalajara), de donde, según parece, proceden las advocaciones marianas extremeñas a la Virgen de Sopetrán.

En efecto, cuenta la tradición que durante la Reconquista bajó la Virgen María al valle de Solanillos (Guadalajara) y desbarató los ejércitos moros de Ali-Maymón reventando las prisiones, grillos y cadenas que atenazaban a los cristianos. El caudillo moro cayó al suelo cegado por el resplandor y preguntó a la Virgen qué quería de él, a lo que ella le contestó que dejara de perseguir a los cristianos. Entonces Ali-Maymón se instruyó en la doctrina cristiana y se convirtió, por lo que la Virgen descendió de la higuera donde se había aparecido, lo llevó a bautizar a una fuente y le puso el nombre de Pedro, que los musulmanes transformaron pronto en Petrán. De ahí la denominación de Sopetrán, porque la Virgen vino "sobre el moro Petrán”. Este mismo musulmán erigió en el siglo XI 
una pequeña ermita cerca de la higuera de la aparición, la devoción empezó a divulgarse y extenderse y se acabó ampliando el santuario y fundándose un convento de agustinos en 1370 (Castellote 2010, 45-46).

Continuando con el relato legendario, el mismo moro Petrán, perseguido por su padre por haberse convertido al cristianismo, hubo de abandonar el Valle de Solanillos y, buscando refugio más seguro, se trasladó a Extremadura, concretamente a las cercanías de Almoharín, donde aprovechó los antiguos restos de una mezquita ya abandonada y arruinada para levantar allí una ermita en honor de la Virgen de Sopetrán. El actual templo de Almoharín es del siglo XVI.

También de Castilla, según la tradición, procede el culto a la Virgen de Sopetrán de Jarandilla, concretamente en el siglo XVII. Parece que hubo una plaga de langosta y los jarandillanos ofrendaron a la Virgen un burro con dos arrobas de cera, pero, como no sabían adónde llevar el asno, dejaron que el animal vagara a su libre albedrío hasta que, después de muchas jornadas de camino, se detuvo en el Monasterio de Sopetrán de Torre del Burgo (Hita, Guadalajara). De ahí la devoción a la Virgen de Sopetrán, a la que construyeron una ermita en el siglo XVIII.

El mismo topónimo que Sopetrán lo tenemos en el nombre de la localidad Sopeira (Huesca), que presenta además otras variantes como Sopetra, Suppetra, Subpetra, Supetra, Sopeyra, etc. (Cortés 2015, 44).

La etimología en todos los casos es sencilla, pues remonta al sintagma latino sub petram, "bajo, debajo de, al pie de la piedra", entendiendo petra en sentido oronímico, esto es, una elevación, cerro o monte pedregosos. Y, efectivamente, estos parajes donde se ubican monasterios y ermitas están "al pie de montes pedregosos". Así, por ejemplo, al fondo de la ermita y del propio Arroyo Sopetrán de Almoharín se observa la pétrea Sierra de San Cristóbal; al fondo de Jarandilla se perciben las pedregosas elevaciones de Gredos.

Tebas (Casas de Millán): Cuenta la leyenda que a un pastorcillo de Casas de Millán (Cáceres), que malvivía con míseros alimentos, iba a visitarle muchas tardes una señora hermosa con su hijo en brazos y le traía frutas y alimentos. Durante estas visitas el joven pastor dialogaba con la señora lleno de felicidad y sólo se entristecía cuando llegaba el momento de despedirse de dicha señora, a la que preguntaba: “¿Ya te vas, señora, ya te vas?”. La señora respondía: "Sí, pero no te preocupes, que mañana nos volveremos a ver". Un día el pastorcillo cayó gravemente enfermo y los demás pastores no lograban curar su dolencia. Durante la noche, el pastor abrió los ojos y dijo: “¿Ya te vas, señora, ya te vas?”. Los demás pastores no veían a nadie y creían que el enfermo estaba delirando por la fiebre, pero sí oyeron sorpresivamente una voz dulce de mujer que 
respondió: "Y tú conmigo". Entonces el joven pastor enfermo murió. Los pastores comprendieron que la mujer que venía a ver asiduamente al pastorcillo era la Virgen María y que era ella la que había respondido invisiblemente, por lo que comenzaron a rezar. Tiempo después, se erigió sobre unos muros visigodos una ermita y se colocó en su altar una virgen tallada según la descripción del pastorcito y de quienes la habían llegado a ver. Y se la denominó Virgen de "te vas" o de Tebas (Sedín 1992). Hasta aquí la leyenda.

El santuario de la Virgen de Tebas, a unos siete kilómetros del pueblo, está ubicado en medio de un paraje accidentado, sobre un cerro pizarroso que constituía una fortaleza inexpugnable, donde romanos y visigodos levantaron antiguos templos que precedieron a la actual ermita de Tebas del siglo XVI. Según Alonso Fernández, en su Historia y anales de la ciudad y obispado de Plasencia:

En las Casas Domillán [está] nuestra Señora de Tiebas" (Férnandez 1627, 17).

Así pues, Tiebas, Tebas, Tevas o Teva, como aún aparece en los mapas catastrales, es el topónimo que hemos de investigar, porque está claro que la Virgen recibió este nombre del paraje donde se apareció, todavía conocido como Tebas. Quizás estemos ante el topónimo mediterráneo Teba, nombre de un pueblo y condado de Málaga, para el que Llorente (1956-1957, 138, n. 23) propone una base indoeuropea *tippe $>$ *tappo $>$ *tappea, "tapia de tierra, colina, terrón", una forma que estaría relacionada con el término prelatino y latino teba, conservada en catalán con el significado de "colina, cerro". También es posible que estemos ante la raíz indoeuropea *teu-/tu-: "hinchar, abultar", que oronímicamente indica una hinchazón o abultamiento del terreno, esto es, una elevación o colina, teniéndonos que remontar al radical sufijado: *teu- $a>$ Teva o Teba. Lo que parece claro es que el topónimo indicaría, en todo caso, el montículo que supone el paraje donde se encuentra la Ermita de Tebas.

Tentudia (Calera de León, Monesterio): El curioso topónimo Tentudía, que da nombre a una sierra, cerro y pico del término municipal de Calera de León y sobre todo al Monasterio de Santa María de Tentudía allí erigido, es antiguo. En fuentes escritas del siglo XIII conservamos la antigua denominación Tudia o Tudía en la cantiga 347 de Alfonso el Sabio, en la que se da cuenta de un milagro que obró la Virgen resucitando a un niño que llevaba ya cuatro días muertos: "Desto direi u miragre que en Tudia avo...". También en el siglo XIV se lee Santa María de Tudia en el Libro de la montería de Alfonso XI. En esta sierra erigió la orden de Calatrava un santuario bajo la advocación de Santa María de Tudia y una casa conventual junto con la encomienda de Tudia, lo que da índice del gran esplendor que hubo de tener. Este culto mariano comenzó hacia 1237, cuando, según cuenta la leyenda, la Virgen intervino milagrosamente 
oyendo las súplicas del Maestre de Santiago Pelay Pérez para poder concluir una batalla contra los moros antes de que acabase el día. El maestre imploró a la Virgen: "¡Santa María, detén tu día!" y dice la tradición que el día se detuvo hasta que los cristianos vencieron a los sarracenos. Así nos cuenta Francisco de Rades el miraglo de Tudia, invirtiendo el orden etimológico natural y considerando que el nombre antiguo, Tudia, es una deformación popular derivada del original Ten tu día, cuando parece claro que es precisamente lo contrario:

El Maestre don Pelay Pérez Correa, haziendo guerra a los moros por la parte de Llerena, huvo con ellos una batalla al pie de Sierra Morena, cerca de donde agora es Sancta María de Tudía. Dizen más, que peleando con ellos muchas horas, sin conoscerse victoria de una parte a otra, como viesse que havía muy poco tiempo de sol, con desseo de vencer aquella batalla y seguir el alcance, suplicó a Dios fuesse servido de hazer que el sol se detuviesse milagrosamente... dixo estas palabras: 'Sancta María detén tu día'... Se detuvo el sol por espacio de tiempo muy notable, hasta que acabó el Maestre su victoria... En memoria deste milagro dizen haverse edificado una yglesia por mandado del Maestre y a costa suya, a la qual puso nombre Sancta María de Ten tu día y agora, corrupto el vocablo, se dize Sancta María de Tudia (Rades 1572, 32r).

El topónimo original debió ser Tudia, sin acento, y posiblemente estaba emparentado con la raíz hidronímica paleoeuropea *tud- (Bascuas 2006), con un sufijo cualitativo -ia. Aún tenemos el pueblo La Tuda (Zamora) y los parajes La Tuda (Pereruela, Zamora; Torrecilla de la Abadesa, Valladolid; Velilla del Río Carrión, Palencia; Toro, Zamora; Tubilla del Agua, Burgos; Cubo de Benavente, Zamora; Villavellid, Valladolid; o Castronuño, Valladolid), Las Tudas (Valladolid), El Tudal (Villanueva de la Vera, Cáceres) o el Arroyo de la Tuda (Zamora). Y tuda es en Zamora, según el DRAE, la cueva hecha en la falda de un monte en la que se guarecen las personas y el ganado. En hidronimia y oronimia puede aplicarse el término a las cuestas blandas y calizas perforadas por la erosión (Sanz 1997, 181-182). Nuestro topónimo mariano, entonces, debió ser en origen Sierra de Tudia, según leemos en los textos más antiguos, y podía estar aludiendo, si realmente está emparentado con la raíz hidronímica paleoeuropea *tud-, a una sierra con numerosas oquedades o cuevas y con abundantes barrancos formados por la erosión del agua en un terreno calizo, tal y como es esta Sierra de Tudia perteneciente al término municipal de Calera de León, lleno de montes y colinas abundantes en piedra caliza. La transformación del topónimo en Tentudía debió verse favorecida por la leyenda y la toponimia mítica, en un intento claro de encontrar un significado racional a una voz cuyo sentido los hablantes de época medieval ya no lograban dilucidar. 
Valbón (Valencia de Alcántara): La Virgen de Valbón fue proclamada patrona de Valencia de Alcántara (Cáceres) en 1618 y posee una ermita de factura gótica, erigida sobre un peñasco granítico en la campiña de Valencia de Alcántara. La advocación a esta Virgen, según la leyenda, la pudieron traer unos peregrinos procedentes de la abadía francesa de Santa María, en la ciudad de Valbonne, algo así como "valle bueno", según Négre $(1991,1145)$. También se cree que el nombre de Valbón podría estar tomado del portugués, con el mismo significado de "valle bueno". Lo cierto es que la ermita y la Virgen entraron en declive y en el olvido tras la proclamación de la Virgen de los Remedios como patrona de la localidad en el siglo XVIII.

El problema estriba en que el topónimo Valbón está corrupto y, según los mapas históricos y actuales, el paraje donde se encuentra la antigua ermita, hoy en ruinas, se denomina Barbón, donde hay un punto geodésico a $602 \mathrm{~m}$., y es precisamente donde nace el Arroyo Barbón, por lo que hemos de pensar que se trata de un orónimo o un hidrónimo en cuya base se encontraría la base prerromana *barb-, "altura" o también "nacimiento de agua, humedal, terreno pantanoso". Sería la misma raíz que tenemos en Barbaño.

\section{REFERENCIAS BIBLIOGRÁFICAS}

Aymard, R. 1995. Les Pyrénées au miroir de leur toponymie, 5 vols. Pau: Uzos. Azedo de Berruezas, G. 1891. Amenidades, florestas y recreos de la provincia de la Vera Alta y Baja en la Extremadura. Sevilla: Rasco.

Barajas Salas, E. 1980. "Topónimos portugueses en Extremadura". Revista de Guimarães, 90 (Jan.-Dez.): 313-325.

Bascuas, E. 2006. Hidronimia y léxico de origen paleoeuropeo en Galicia. Sada, A Coruña: E. do Castro.

Cabeza Quiles, F. 2014. A toponimia celta de Galicia A Coruña: E. Toxosoutos.

Castellote Herrero, E. 2010. Libros de milagros y milagros en Guadalajara (siglos XVI-XVIII). Madrid: CSIC.

Coca Tamame, I. 1993. Toponimia de la Ribera de Cañedo (Provincia de Salamanca). Salamanca: Diputación de Salamanca.

Coria, F. de. 1608. Descripción e historia general de la provincia de Extremadura, que trata de sus antigüedades y grandeza..., y fundación de sus iglesias y obispados, compuesto por Fray Francisco de Coria, de la Provincia de San Gabriel, de los descalzos de San Francisco. Manuscrito 23044 de la Biblioteca Nacional de España.

Cortés Valenciano, M. 2008. Toponimia de la villa de Tauste. Zaragoza: Asociación Cultural "El Patiaz". 
Cortés Valenciano, M. 2015. "Los topónimos terminados en -ún en el Alto Aragón". Alazet 27: 9-58.

Díez Asensio, J. 1990. "Toponomástica antigua prerromana de las tierras al sur del Duero Medio". Historia Antiqua XIV: 179-199.

Domínguez Moreno, J. M. .1991. "Microlitos y megalitos funerarios en Alcántara". Revista de Floklore 125: 147-156.

Edmondson, J. 2001. "El redescubrimiento de los monumentos funerarios con retrato. Siglos XVI-XX". En Imagen y memoria. Monumentos funerarios con retratos en la colonia Augusta Emerita, editado por J. Edmondson, T. Nogales, y W. Trillmich, 105-112. Madrid: Real Academia de la HistoriaMuseo Nacional de Arte Romano.

Fernández A. 1627. Historia y anales de la ciudad y obispado de Plasencia. Madrid: Juan González.

Fernández Sánchez, T. 1994. María en los pueblos de España ... Guía para visitar los Santuarios Marianos de Extremadura. Madrid: Ediciones Encuentro.

Galmés de Fuentes, Á. 2000. Los topónimos: sus blasones y trofeos (la toponimia mítica). Madrid: RAH.

Gordón Peral M.D. y S. Ruhstaller. 1992. "Análisis etimológico de la macrotoponimia onubense". Huelva en su historia 4: 421-440.

Llorente Maldonado, A. 1956-1957. "Las 'Palabras pirenaicas de origen prerromano' de J. Hubschmid y su importancia para la lingüística peninsular”. Archivo de Filología Aragonesa VIII-IX: 127-157.

Madruga, J. V. y J. L. Gómez Pantoja. 2021. "Agustín Sánchez Rodrigo y la epigrafía en Serradilla, Cáceres, y sus alrededores". Historia Antigua 25: 173-190.

Mañas Núñez, M. 2019. "Raíces prerromanas en falsos zootopónimos de la provincia de Cáceres". Revista de Filología Románica 36: 29-44.

Mariana Navarro, A. 2013. "Leyendas marianas e imágenes milagrosas en la historia de la religiosidad popular de Andalucía (siglos XII-XVII)". En la España Medieval 36: 327-356.

Martín Nieto, D. Á. 2009. "Santa María de Almocóvar de Alcántara en el siglo XVI". Revista de Estudios Extremeños 56, n. 2: 643-750.

Moralejo, J. J. 2005. "Hidrónimos galaicos con sufijo - antia". Acta Paleohispanica 5: 837-860.

Moralejo Lasso, A. 1977. Toponimia gallega y leonesa. Santiago: Pico Sacro.

Muñoz de San Pedro, M. 1953. "La desaparecida Orden de Caballeros de Monfragüe". Hidalguía 1: 69-76.

Nègre, E. 1991. Toponymie générale de la France, II. Genève: Droz.

Pérez Vilatela, L. 2000. Lusitania. Historia y etnología. Madrid: RAH.

Rades y Andrada, F. 1572. Chrónica de las tres Órdenes y Cavallerías de Sanctiago, Calatrava y Alcántara. Toledo: Juan de Ayala. 
Ramos Rubio, J. A. 2018. "El castillo de Trujillo". El Cronista Extremeño (Boletín de la Asociación de Cronistas Oficiales de Extremadura) II. 10 (Mayo): 4-61.

Rodríguez Plasencia, J. L. 2011. "Apariciones marianas en Extremadura II”. Revista de Folklore 358: 16-26.

Rodríguez Plasencia, J. L. 2012. "Apariciones marianas en Extremadura III". Revista de Folklore 363: 33-45.

Rodríguez Plasencia, J. L. 2013. "El Santuario de la Virgen de Navelonga, de Cilleros. ¿Un lugar mágico". Alcántara 78: 83-96.

Ruhstaller, S. 1995. Materiales para la lexicología histórica. Estudio y repertorio alfabético de las formas léxicas toponímicas contenidas en el 'Libro de la Montería' de Alfonso XI. Tübingen: Verlag.

Ruhstaller, S. 2010. "La investigación sobre toponimia de Andalucía Occidental". En Toponimia de España. Estado actual y perspectivas de investigación, coordinado por M. D. Gordón Peral. Berlin, New York: De Gruyter.

Sánchez Salor, E. 1977. "Sobre el hidrónimo cacereño Salor". Alcántara 33, n. 188: 11-18.

Sánchez Salor, E. 1999. "Extremadura y los nombres de sus lugares". Boletín de la Real Academia de Extremadura de las Letras y las Artes X: 105-144.

Sanz Alonso, B. 1997. Toponimia de la provincia de Valladolid: las cuencas del Duero, Pisuerga y Esgueva. Valladolid: Universidad de Valladolid.

Sedín Blázquez, J. 1992. Leyendas extremeñas. Madrid: Everest.

Selfa Sastre, M. 2001. Toponimia de Ribagorza. Municipio de Campo. Lleida: Diputación General de Aragón, E. de la Universitat de Lleida.

Simón Pardo, J. 2003. La devoción a la Virgen en España. Historias y leyendas. Madrid: Ediciones Palabra.

Torres y Tapia, A. 1763. Crónica de la Orden de Alcántara. I. Madrid: G. Rodríguez.

Vallvé Bermejo, J. 1999. "Historia, toponimia y lengua”. En El saber en el AlAndalus. Textos y estudios, II, editado por J. M. Carabaza Bravo y A. T.. M. Essawy, 99-120. Sevilla: Universidad de Sevilla.

Manuel Mañas Núñez Facultad de Filosofía y Letras Universidad de Extremadura Avda. de la Universidad s/n 10003 - Cáceres (España) https://orcid.org/0000-0001-7351-0077 
